\title{
TREATMENT OF TANNERY EFFLUENT USING PHYSICAL (COIR PITH) AND BIOLOGICAL CONSORTIUM (NAVA RASA KARAISAL) METHODS TO CHARACTERIZE AS BASAL FERTILIZER
}

\author{
James Jeya Josepine. A. ${ }^{1}$, Jenifer. G. P. ${ }^{2}$ and Malliga. P. ${ }^{{ }^{*}}$ \\ ${ }^{1 \& 2}$ Department of Marine Biotechnology, ${ }^{3}$ Professor \& Head, \\ Department of Marine Biotechnology, Bharathidasan University, Tiruchirappalli, India \\ *Email: malliga.p@bdu.ac.in
}

\begin{abstract}
Tannery industry processes are among the most environmentally polluting industrial processes, because they produce different colored waste water that are heavily damage the environment and surrounding places. The experiment was conducted with different treatments of tannery effluent (TN) with coir pith (CP) and Nava rasa karaisal (NRK) and analysed the physical and chemical parameters. There are fifty one parameters like $\mathrm{pH}$, salinity, $\mathrm{Na}, \mathrm{Pb}, \mathrm{Hg}$, $\mathrm{Zn}$ etc. which were analysed and the results showed that the chemical absorption of treated tannery effluent was found better when compared with the other treatments. Hence, the present investigation revealed that the solid waste combination of (Tannery effluent + Coir pith + Nava Rasa Karaisal) can be used as organic fertilizers for plant growth and developments.
\end{abstract}

Key words: Tannery effluent, Coir pith, NRK, Bio fertilizer, BOD, COD

\section{Introduction}

The tannery industries are the backbone of the leather industries and the colored wastewater generated from the various processing units are due to bleaching, mercerizing, dyeing, printing and packing which require large amount of synthetic chemicals. Further, the effluent from the tannery industries is usually discharged with all types of pollutant into the sewage system or neighboring land causing serious environmental problems (Murali et al., 2013). Leather industry is one of the traditional and oldest industries in India and one of the leading foreign exchange earners for the country. But the industry is plagued by heavy pollution stress on the environment, thus negating some of the other societal benefits the industry has merited. Production of leather, leather goods, boards and fur produces numerous by-products like solid waste, and high amounts of waste water containing different loads of pollutants and toxic chemicals.

Thamizhiniyan et al. (2009) earlier reported that water is the main source for industries to dispose waste materials. It is found that almost all rivers are polluted in most of the stretches by some industries. Toxic heavy metals, which are of concern, like chromium ( $\mathrm{Cr}$ ), lead (Pb), zinc $(\mathrm{Zn})$, arsenic $(\mathrm{As})$, copper $(\mathrm{Cu})$, nickel $(\mathrm{Ni})$, cobalt $(\mathrm{Co})$, cadmium $(\mathrm{Cd})$ and mercury $(\mathrm{Hg})$, are not biodegradable. So they tend to accumulate in the living organisms and lead to different types of diseases and disorders which finally threaten human life (Monachese et al., 2012). As solution to this problem, some methods like reverse osmosis, ion exchange, membrane filtration and electro dialysis are used effectively for removing these metals. But they are costly and generate concentrated wastes that require subsequent treatment for disposal. Biological removal may provide a suitable means for treatment of wastewater (Lovely and Coates 1997 and Rittmann et al., 2004). The cyanobacteria showed enormous potential in waste water and industrial effluent treatment, bioremediation of aquatic and terrestrial habitats, chemical industries, bio fertilizers, (Malliga et al., 1996, Abraham et al., 2002, Malliga and Viswajith, 2005 \& 2007, Chandrasekar et al., 2008, Pazhanivel et al., 2011, Bhuvaneshwari et al., 2011, 
Subramaniyan and Malliga, 2011, Subramaniyan et al., 2012, Durai raju and Malliga, 2013, Shanmugapriya and Malliga, 2013, Lakshmi and Malliga, 2014, Nivetha et al., 2014, Lakshmi et al., 2015 and Jenny and Malliga, 2018), feed etc., (Cairns and Dickson, 1971 and Kulasooriya, 2011).

Coir pith is the by-product of coir yarn industries which constitute about 70percent husk. As coir pith has high content of lignin and it takes decades to decompose, it causes environmental hazards because of its disposal problems (Krishnamoorthy et al., 2012). The water holding capacity of coir pith is enormous which a boost to the growth of cyanobacteria was. The non-nitrogen fixing cyanobacteria which enriched the phosphorus and potassium contents in the soil also played a major role in food, feed and medicine. Christopher et al. (2007) concluded that the coir pith based cyanobacterial bio fertilizer could be an effective alternative or combination with chemical fertilizer. The recent research shows that coir pith can be partially decomposed through the action of cyanobacteria and can be used as a bio fertilizer for all varieties of food crops (Silambuselvi et al., 2014, Durai Raju and Malliga, 2013 and Jenny and Malliga, 2016). Nava Rasa Karaisal is a concoction prepared by mixing of nine products and used in traditional rituals. It enriches the soil and provides the entire nutrient requirements for the growth of the plant. Physiochemical and biological properties of Nava Rasa Karaisal revealed that they possess almost all the macro nutrients, micro nutrients and growth hormones required for crop growth. Nava Rasa Karaisal contains rich source of nitrogen and valuable microorganisms which naturally enhances soil fertility and also Kalaibharathi et al. (2019) reported that the Nava rasa karaisal enriches the soil, plant and provides all the nutrients required for the plant growth. NRK is also called as microbial consortia used in treatment for seed and planting material. In this current research, five treatments in which physiochemical characterizations were analyzed to find out the reduction of different chemicals and heavy metals.

\section{Materials and Methods}

The effluents were collected from the tannery industry at Sempattu Unit, Tiruchirappalli, Tamil Nadu, India and coir pith was collected from coir industries near Samayapuram, Tiruchirappalli, Tamil Nadu, India. The collected effluent was mixed with NRK, CP separately and in combinations and the effluents were taken for the following physical and chemical parameters like Colour (IS: 2720 part I (1987), pH (APHA 1989), TDS (IS: 3025 Part 16: 1984), TSS (IS: 3025 Part 17: 1984), Alkalinity as $\mathrm{CaCO}_{3}$ (IS: 3025 Part 23: 1986), Hardness as $\mathrm{CaCO}_{3}$ (IS: 3025 Part 21: 2009), Chloride (APHA, 1989), Nitrite (APHA, 1995), Nitrate (APHA 1976), Salinity (APHA 22nd Ed, 2012), Potassium (US EPA 3050 B, 1996), Biological Oxygen Demand (BOD) (IS: 3025 Part 58: 2006, RA 2012), Chemical Oxygen Demand (COD) (IS: 3025 Part 44: 1993 RA 2009), Calcium and Magnesium (Govindaraju et al., 2001), Zinc (US EPA 3050 B, 1996) and Selenium (IS: 3025 Part 56: 2003) which were analyzed through the standard techniques (Table $1 \&$ Table 2).

\section{Result and Discussion}

Bio-fertilizers are ecofriendly and supply the nutrient inputs of microbial origin for plant growth and developments. The organic fertilizers and manure can increase the quality and improve the yield paving the way for sustainable agriculture. In the present investigation, physiochemical parameters were analyzed for the collected untreated tannery effluent and treated tannery effluent with coir pith and Nava Rasa Karaisal. The tannery effluent exists as pale brown in colour; Nava Rasa Karaisal was white with gray in colour and exhibiting microbial growth; Tannery effluent with Nava rasa karaisal colour was changed in to very light brown and also showing growth of microorganisms; Tannery effluent with Coir pith colour was light brown and Tannery effluent with Coir pith and Nava Rasa Karaisal after treatment the colour was changed 
from pale brown to dark brown in colour because of microbial effects (Plate 1;Table 1 \&Table 2,). Supporting evidence showed that untreated effluent color was brownish black while treatment with sorghum the color changed into muddy grey in colour (Gark and Kaushik, 2009) and untreated industrial effluent was grey in colour and after treatment with Pseudomonas sp. turn in yellow colour on the observation of $15^{\text {th }}$ day (Susithra et al., 2009). The untreated tannery effluent colour changed after treatment from dark brown to pale brown (Murali et al., 2013). Initially tannery effluent colour was brown and after treated by bacterial consortium (Bacillus sp., Pseudomonas sp. and Micrococcus sp.) the color was changed into brown to light brown on 72 hrs (Mythili and Karthikeyan, 2011). The color of leather industrial effluent is black before treatment but, after the degradation with native fungus Aspergillus niger and non- native fungus Aspergillus flavus the color changed into almost colorless (Noorjahan, 2014). The turbidity of tannery effluent was not changed after treatment with the TN with CP and NRK (Table 1). Initial $\mathrm{pH}$ of the tannery effluent was 8.87 and reduced to $\mathrm{pH} 6.73(\mathrm{TN}+\mathrm{CP}+\mathrm{NRK})$ and $6.64(\mathrm{TN}+\mathrm{CP})$ in solid waste treatments (Table 1 \& Table 2). Similarly, Mohammed Assou et al. (2014) showed that the optimization of multiple responses allowed coagulants and flocculants doses to be minimized while maximizing the percentage of turbidity 97 percent removal.

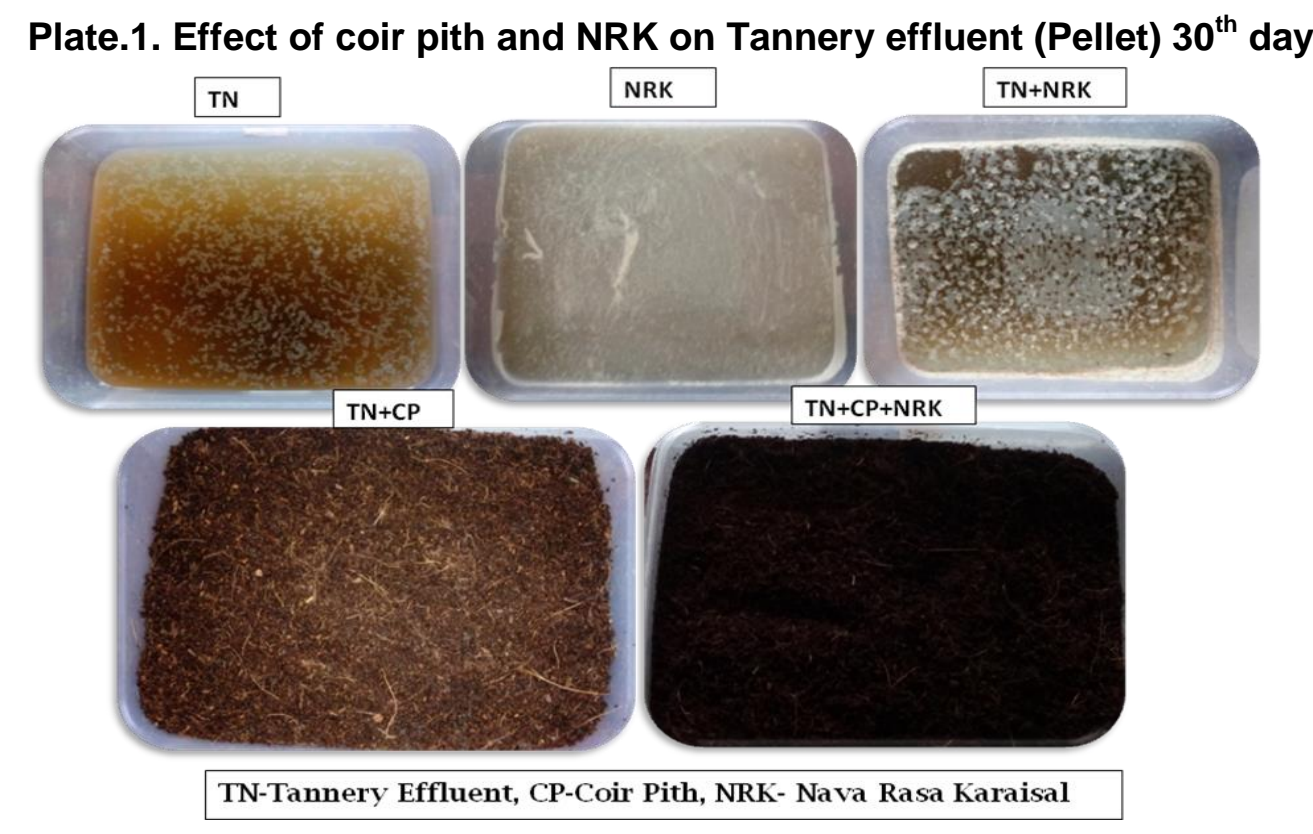

The findings were similar to the observations of Riyaz et al. (2019) which showed that the $\mathrm{pH}$ of untreated (TN) and treated tannery effluent with coir pith, cyanobacteria $(\mathrm{TN}+\mathrm{CP}+\mathrm{CB}+\mathrm{NRK})$ values showed as 8.87 and 6.56. Dominic et al. (2009) revealed that Chlorella vulgaris, Synechocystis salina and Gloeocapsa gelatinosa treated water samples showed increased $\mathrm{pH}$ from 6 to $8.1,6$ to 8 and 6 to 7.9. Untreated industrial effluent the $\mathrm{pH}$ was 3.90, after treated with Pseudomonas sp. the $\mathrm{pH}$ was increased to 7.0 on $15^{\text {th }}$ day (Susithra et al., 2009).

In the untreated tannery effluent specific conductance was recorded and showed reduction in liquid treatments of $\mathrm{TN}+\mathrm{NRK}$ (Table 1). Reduced specific conductance level was observed in treated tannery effluent. This could be due to addition of Nava rasa karaisal. The total dissolved solid (TDS), Total Suspended Solids (TSS), Total Solids and Residual free Chlorine values exhibited slight reduction in treated tannery effluent when compared to untreated tannery effluent. This could be the effect of microbial flora from NRK (Table 1). Initially untreated tannery effluent have high level of TDS $(2840 \mathrm{mg} / \mathrm{l})$ after inoculation of three species these levels were reduced such as Bacillus subtilis $(2.5 \mathrm{~g} / \mathrm{l})$, Pseudomonas aerginosa $(2.2 \mathrm{~g} / \mathrm{l})$ and Saccharamyces cerevisiae (2.5 g/l) (Sivaruban et al., 2014). Sangita et al, (2013) revealed 
that untreated tannery effluent was treated with Pseudomonas sp TSS levels were decreased from 1000 to $500 \mathrm{mg} / \mathrm{l}$ when compared to untreated tannery effluent reveling the high level of total alkalinity and hardness in untreated tannery effluent but, the tannery effluent treated with NRK and there by the action of microorganisms could be reduce the above said contents (Table 1). Sugasini and Rajagopal (2015) revealed that initially untreated tannery effluent high level of total Alkalinity (as CaCO3) $1021.5 \mathrm{mg} / \mathrm{l}$ (I year), $1187.2 \mathrm{mg} / \mathrm{l}$ (II year) and total Hardness 1512.5 $\mathrm{mg} / \mathrm{l}$ (I year), $1320.8 \mathrm{mg} / \mathrm{l}$ (II year) after treated industrial common treatment these level were reduced alkalinity $516.8 \mathrm{mg} / \mathrm{l}$ (I year), $665.5 \mathrm{mg} / \mathrm{l}$ (II year) and total hardness $1129.2 \mathrm{mg} / \mathrm{l}$ (I year) and $1245.8 \mathrm{mg} / \mathrm{l}$ (II year).

Table 01: Physicochemical Parameter Analysis of Untreated and Treated Tannery Effluent (Foliar)

\begin{tabular}{|c|c|c|c|c|c|}
\hline \multirow[t]{2}{*}{$\#$} & \multirow[t]{2}{*}{ Parameter } & \multicolumn{4}{|c|}{ Liquid waste Treatments } \\
\hline & & $\mathrm{TN}^{*}$ & NRK $^{*}$ & TN+NRK & unit \\
\hline 1 & Colour & Dark brown & Yellow & Very light brown & Hazen \\
\hline 2 & Turbidity & Less than 20 & Less than 20 & Less than 20 & NTU \\
\hline 3 & $\mathrm{pH} @ 25^{\circ} \mathrm{c}$ & 8.87 & 5.64 & 8.87 & - \\
\hline 4 & Specific conductance @25 c & 9.88 & 1.57 & 7.895 & $\mathrm{mS} / \mathrm{cm}$ \\
\hline 5 & Total Dissolved solids (TDS) & 44680 & 9160 & 37600 & $\mathrm{mg} / \mathrm{lit}$ \\
\hline 6 & Total suspended solids as TSS & 88.9 & 148.26 & 74.5 & $\mathrm{mg} / \mathrm{lit}$ \\
\hline 7 & Total Solids & 760 & 834 & 710 & $\mathrm{mg} / \mathrm{lit}$ \\
\hline 8 & Residual Free Chlorine as $\mathrm{Cl}_{2}$ & 3460 & 3670 & 2980 & $\mathrm{mg} / \mathrm{lit}$ \\
\hline 9 & Total Alkalinity as $\mathrm{CaCO}_{3}$ & 10500 & 2870 & 8890 & $\mathrm{mg} / \mathrm{lit}$ \\
\hline 10 & Total Hardness as $\mathrm{CaCO}_{3}$ & 19290 & 4680 & 16720 & $\mathrm{mg} / \mathrm{lit}$ \\
\hline 11 & Oil and Grease & 5.53 & 5.94 & 4.82 & $\mathrm{mg} / \mathrm{lit}$ \\
\hline 12 & Total Sulphide as $\mathrm{SO}_{2}$ & 7.82 & 12.4 & 7.24 & $\mathrm{mg} / \mathrm{lit}$ \\
\hline 13 & Chloride as $\mathrm{Cl}^{-}$ & 7860 & 4260 & 7120 & $\mathrm{mg} / \mathrm{lit}$ \\
\hline 14 & Total phosphorus as $\mathrm{PO}_{4}^{-}$ & 290 & 320 & 255 & $\mathrm{mg} / \mathrm{lit}$ \\
\hline 15 & Nitrates as $\mathrm{NO}_{3}$ & 240 & 172 & 234 & $\mathrm{mg} / \mathrm{lit}$ \\
\hline 16 & Nitrates as $\mathrm{NO}_{2}$ & 12.8 & 10.5 & 10.8 & $\mathrm{mg} / \mathrm{lit}$ \\
\hline 17 & Total nitrogen & 18.84 & 12.56 & 15.42 & $\mathrm{mg} / \mathrm{lit}$ \\
\hline 18 & Phenolic compounds as $\mathrm{CH}_{5} \mathrm{OH}$ & 2.82 & 3.82 & 2.5 & $\mathrm{mg} / \mathrm{lit}$ \\
\hline 19 & Sodium as $\mathrm{Na}$ & 3.8 & 1.6 & 3.64 & $\mathrm{mg} / \mathrm{lit}$ \\
\hline 20 & Potassium as $\mathrm{K}$ & 2.25 & 1.86 & 2.2 & $\mathrm{mg} / \mathrm{lit}$ \\
\hline 21 & Biochemical Oxygen Demand & 356 & 545 & 276 & $\mathrm{mg} / \mathrm{lit}$ \\
\hline 22 & Chemical Oxygen Demand & 1980 & 2890 & 1540 & $\mathrm{mg} / \mathrm{lit}$ \\
\hline 23 & Arsenic as As & 2.8 & 3 & 2.6 & $\mathrm{mg} / \mathrm{lit}$ \\
\hline 24 & Cadmium as Cd & 10 & 6.45 & 8.65 & $\mathrm{mg} / \mathrm{lit}$ \\
\hline 25 & Copper as $\mathrm{Cu}$ & 25 & 16.7 & 23.5 & $\mathrm{mg} / \mathrm{lit}$ \\
\hline 26 & Lead as Pb & 10.3 & 8.5 & 9.7 & $\mathrm{mg} / \mathrm{lit}$ \\
\hline 27 & Mercury as $\mathrm{Hg}$ & 1.2 & 1.3 & 1.1 & $\mathrm{mg} / \mathrm{lit}$ \\
\hline 28 & Zinc as Zn & 12.4 & 16.85 & 11 & $\mathrm{mg} / \mathrm{lit}$ \\
\hline 29 & Total Chromium & 84.6 & 24.62 & 62.4 & $\mathrm{mg} / \mathrm{lit}$ \\
\hline 30 & Iron as Fe & 20.5 & 36.84 & 18.2 & $\mathrm{mg} / \mathrm{lit}$ \\
\hline 31 & Nickel & 6.7 & 6.25 & 6 & $\mathrm{mg} / \mathrm{lit}$ \\
\hline 32 & Selenium as Se & 5.5 & 2.5 & 5.2 & $\mathrm{mg} / \mathrm{lit}$ \\
\hline 33 & Manganese as $\mathrm{Mn}$ & 5.6 & 3 & 5.2 & $\mathrm{mg} / \mathrm{lit}$ \\
\hline 34 & Fluoride as $\mathrm{F}$ & 12 & 10.64 & 8.8 & $\mathrm{mg} / \mathrm{lit}$ \\
\hline
\end{tabular}

*TN-Tannery effluent, NRK-Nava Rasa Karaisal.

The presence of Oil and Grease, $\mathrm{SO}_{2}$, Chloride, $\mathrm{PO}_{4}$, Nitrates, Nitrites contents exhibited moderate changes in $\mathrm{TN}+\mathrm{NRK}$ when compared with untreated tannery effluent (Table 1). The supporting evidence showed that in the untreated industrial effluent chloride level was very high ( $3 \mathrm{mg} / \mathrm{ml}$ ) but after treated with Pseudomonas sp these levels found reduced $\left(2 \mathrm{mg} / \mathrm{ml}\right.$ ) on $15^{\text {th }}$ day (Susithra et al., 2009). Nantha et al, (2010) reported that removal of Chloride from the tannery effluent was observed due to the inoculation of Nostoc sp chloride level was $89.1 \mathrm{mg} / \mathrm{l}$ initially and it decreased $32.3 \mathrm{mg} / \mathrm{l}$ on $28^{\text {th }}$ day onwards. This results are supported by the studies made by Srinivas et al, (2012) stating that untreated tannery effluent Nitrate and Nitrites 
levels were recorded initially $90 \mathrm{mg} / \mathrm{l}$ and $48 \mathrm{mg} / \mathrm{l}$ after inoculation of Pseudomonas sp.; it was reduced to $46 \mathrm{mg} / \mathrm{l}$ and $21 \mathrm{mg} / \mathrm{l}$ respectively on $15^{\text {th }}$ day. The salinity, acidity and humidity showed not much variation in untreated effluents and treated effluents and also other parameters like water activity, temperature, soil moisture, silt, clay, sand, electrical conductivity, Permeability, Organic matter and total nitrogen were not changed after treated with coir pith and NRK (Table 2).

Table 02: Physicochemical Parameter Analysis of Treated Tannery Effluent (Basal)

\begin{tabular}{|c|c|c|c|c|}
\hline \multirow{2}{*}{$\#$} & \multirow{2}{*}{ Parameter } & \multicolumn{3}{|c|}{ Solid waste treatments } \\
\hline & & $\mathrm{TN}^{*}+\mathrm{CP}^{*}$ & $\mathrm{TN}+\mathrm{CP}+\mathrm{NRK}^{*}$ & unit \\
\hline 1. & Color & Dark brown & Dark brown & - \\
\hline 2. & $\mathrm{PH}$ & 6.64 & 6.73 & - \\
\hline 3. & Salinity (Total) & 0.687 & 0.695 & $\mathrm{mmhos} / \mathrm{cm}$ \\
\hline 4. & Acidity & 4.92 & 5.38 & $\mathrm{~g} / \mathrm{m}^{3}$ \\
\hline 5. & Humidity & 29.5 & 29.5 & - \\
\hline 6. & Water activity & Less & less & ${ }^{\circ} \mathrm{C}$ \\
\hline 7. & Temperature & 25.95 & 25.9 & percent \\
\hline 8. & Soil moisture & 16.82 & 16.54 & percent \\
\hline 9. & Silt & 3.3 & 3.22 & percent \\
\hline 10. & Clay & 4.54 & 4.45 & percent \\
\hline 11. & Sand & 1.42 & 1.12 & $\mathrm{mmhos} / \mathrm{cm}$ \\
\hline 12. & Electrical conductivity & 0.675 & 0.696 & $\mathrm{~mm} / \mathrm{hr}$ \\
\hline 13. & Permeability & 3.2 & 0.352 & percent \\
\hline 14. & Organic matter & 12.56 & 14.85 & percent \\
\hline 15. & Nitrogen & 1.25 & 1.37 & percent \\
\hline 16. & Sodium & 0.08 & 0.09 & percent \\
\hline 17. & Potassium & 2.34 & 2.56 & percent \\
\hline 18. & Phosphate & 0.62 & 0.7 & percent \\
\hline 19. & Lime status & 1.2 & 1.1 & percent \\
\hline 20. & Magnesium & 0.53 & 0.86 & percent \\
\hline 21. & Calcium & 0.34 & 0.83 & percent \\
\hline 22. & Copper & 1.1 & 1 & $\mathrm{mg} / \mathrm{kg}$ \\
\hline 23. & Mercury & 0.3 & 0.3 & $\mathrm{mg} / \mathrm{kg}$ \\
\hline 24. & Zinc & 1.86 & 2.25 & percent \\
\hline 25. & Chromium & 2.2 & 2 & $\mathrm{mg} / \mathrm{kg}$ \\
\hline 26. & Aluminum & 1.5 & 1.32 & $\mathrm{mg} / \mathrm{kg}$ \\
\hline 27. & Selenium & 0.4 & 0.4 & $\mathrm{mg} / \mathrm{kg}$ \\
\hline 28. & Silver & 0.5 & 0.5 & $\mathrm{mg} / \mathrm{kg}$ \\
\hline 29. & Fluoride & 2.45 & 2.4 & $\mathrm{mg} / \mathrm{kg}$ \\
\hline
\end{tabular}

${ }^{*}$ TN-Tannery effluent, CP-Coir pith, NRK-Nava Rasa Karaisal.

Sodium, Potassium and Phenolic compounds in treated tannery effluent with NRK moderately less elevated when compared with untreated tannery effluent and in NRK (Table 1 \& Table 2). The untreated tannery effluent sodium and Potassium level were found initially (2087 $\mathrm{mg} / \mathrm{L}$ (I year), $1367.5 \mathrm{mg} / \mathrm{L}$ (II year) and (318.5 mg/L (I year), $240.4 \mathrm{mg} / \mathrm{L}$ (II year) after industrial tanners treatment these levels were reduced $1760.7 \mathrm{mg} / \mathrm{l}$ (I year), $1120.8 \mathrm{mg} / \mathrm{l}$ (II year) and $270.8 \mathrm{mg} / \mathrm{l}$ (I year), $212.5 \mathrm{mg} / \mathrm{l}$ (II year) Sugasini and Rajagopal (2015). The BOD and COD levels were observed the reduction in combined treatments of $\mathrm{TN}+\mathrm{NRK}$ which indicates the demand of biological oxygen due to the decomposition of inorganic and organic compounds 
present in tannery effluent by bacteria from NRK (Table 1). The findings were similar to the observations of Mythili and Karthikeyan (2011) which showed that the value of BOD and COD of untreated tannery effluent of $(1260 \mathrm{mg} / \mathrm{l})$ and $(2035 \mathrm{mg} / \mathrm{l})$; after treatment with (Bacillus sp, Pseudomonas sp, Micrococcus sp) these levels were reduced BOD (28 mg/l) and COD (230 $\mathrm{mg} / \mathrm{l})$ around $72 \mathrm{hrs}$. Untreated tannery effluent BOD (1.2 $\mathrm{g} / \mathrm{l})$ and COD $(2.3 \mathrm{~g} / \mathrm{l})$ level was high; after treated with Pseudomonas sp these level were reduced BOD $(0.9 \mathrm{~g} / \mathrm{l})$ and COD $(0.3 \mathrm{~g} / \mathrm{l})$ on $20^{\text {th }}$ day (Anamika et al., 2013). The analysed results showed that the presence of Phosphate, Lime content, Magnesium and Calcium in tannery effluent with coir pith and NRK (Table 2). The untreated tannery effluent calcium levels were found initially $83 \mathrm{mg} / \mathrm{l}$; after inoculation of Pseudomonas sp it was reduced to $42 \mathrm{mg} / \mathrm{l}$ on $15^{\text {th }}$ day (Srinivas et al., 2012).

The untreated tannery effluent exhibited the presence of heavy metals. In the treated effluent with coir pith and NRK showed moderate reduction of all heavy metals (Table $1 \&$ Table 2). This could be due to adsorption and absorption of the metals by coir pith and microorganisms. This results are supported by the studies made by Riyaz et al. (2019), stating that reduction of heavy metals like Iron, chromium, lead, Nickel, arsenic, fluoride, Manganese and selenium with all the treatments notably with the combined treatment of Lyngbya sp. with coir pith in tannery effluent. Initially tannery effluent present in high level of Chromium (12.8 $\mathrm{mg} / \mathrm{l})$, Copper $(4.90 \mathrm{mg} / \mathrm{l})$, Lead $(3.2 \mathrm{mg} / \mathrm{l})$ and Zinc $(7.4 \mathrm{mg} / \mathrm{l})$; after treated by Scenedesmus sp. These levels were reduced Chromium (5.4 mg/l), Copper $(1.00 \mathrm{mg} / \mathrm{l})$, Lead $(1.91 \mathrm{mg} / \mathrm{l})$ and Zinc (2.52 mg/l) on $12^{\text {th }}$ day (Kayilveedu et al., 2015). Similarly, Selvi et al. (2012) also observed that higher reduction of $\mathrm{Pb}$ (90 percent), $\mathrm{Cu}$ (85 percent), $\mathrm{Zn}$ (80 percent) and $\mathrm{Cr}$ (70 percent) from treated tannery effluent using isolated of Pseudomonas sp.

\section{Conclusion}

The present study revealed that TDS, TSS, Alkalinity and Hardness $\left(\mathrm{CaCO}_{3}\right)$, Sodium, BOD, COD, Zinc, Chromium, Selenium and Fluoride content in tannery effluent reduced by the addition of coir pith and Nava rasa Karaisal. Hence, the above treated tannery effluent can be used for as eco-friendly fertilizer and this also leads to soil enrichment, restoring the soil fertility, protecting it against drought, soil disease, stimulate plant growth and plant resistant to unfavourable environmental stresses.

\section{Acknowledgement}

The author thanks the COIR BOARD for providing financial assistance for this project.

\section{References}

1. Christopher, A.; Viswajith, V., Prabha, S., Sundhar, K. and Malliga, P. (2007). Effect of coir pith based cyanobacterial basal and foliar bio fertilizer on Basella rubra L. Acta agriculturae Slovenica. 89-1.59-63.

2. Abraham, W. R.; Nogales, B., Golyshin, P. N., Pieper, D. H. and Timmis, K. N. (2002). Polychlorinated biphenyl-degrading microbial communities in soils and sediments, Curr Opin Microbiol, 5, pp 246-53.

3. Anamika, A., H. P. Singh and J. P. N. Rai. (2013). Bioremediation of tannery effluent by using Pseudomonas fluroscenes and Eichhornia crassipes and its effect on wheat seed germination and plant growth. G- Journal of Environmental Science and Technology, 1(1): 20-23.

4. American Public Health Association (APHA), (1976). Standard Methods for the Examination of Water and Wastewater. 14th Edition, American Public Health Association, Washington DC, 1193.

5. American Public Health Association (APHA), (1989). Standard methods for Examination of water and waste water, APHA, AWWA, WPCF, New York, 17th Ed.

6. American Public Health Association (APHA), 1995. Standard Methods for the Examination of Water and Wastewater. 19th Edition, American Public Health Association Inc., New York.

7. American Public Health Association (APHA), (2012). Water and wastewater manual available now in 22nd edition, The Nation's Health, 42 (1) 2. 
8. Bhuvaneshwari, B.; Subramaniyan V, Malliga P. (2011). Comparative studies of Cyanopith and Cyanospray bio fertilizers with chemical fertilizers on sunflowers (Helianthus annuus L.). International Journal of Environmental Sciences. Vol.1 (7): 1515-1525.

9. Cairns, J. and Dickson, K. (1971). A simple method for biological assessment of the effect of waste discharge on the aquatic bottom dwelling organisms, J. Wat Polln. Control Fed, pp 775.

10. Chandrasekar, P.; Prabha, D.S., Subramanian, V., Sharma, U.C., Anitha Das, R., Bhuvaneshwari, P and Malliga, P. (2008). Optimization of Cyanopith Biofertilizer for Groundnut (Arachis hypogaea L.) Cultivation. BDU. J. Sci. \& Tech. 2: 324- 331.

11. Dominic, V.; Soumya, M. and Nisha, M. C. (2009). Phycoremediation efficiency of three micro algae Chlorella vulgaris, Synechocystis salaina and Gleocapsa salina and Gloeocapsa gelatinosa. SB Academic Review, 1 (2): 138-146.

12. Durai Raju, S. and Malliga, P. (2013). Effect of coir pith based cyanobacterial bio fertilizers, Jiwamrita and their combination on morphometric parameters of Oryza sativa L. Indian journal of natural sciences. 3(18), 1325-1331.

13. Gark, V. K. and Kaushik, P. (2009). Influence of textile mill waste water irrigation on the growth of Sorghum cultivars. Applied ecology and Environmental Research. 6 (2): 1-12.

14. Govindaraju. P.; Devaki. T., and Subash Chandrabose M. (2001). In Practical plant biochemistry, Rasi publication, Trichy, Tamil Nadu, India.

15. Indian standard methods of test for soil (IS), 2720, part I, 1987.

16. Indian standard methods of test for soil (IS), 3025, part 23, (1986). Methods of sampling and test (Physical and Chemical) for water and waste water.

17. Indian standard methods of test for soil, 3025, Part 16, (1984). Method of Sampling and Test (Physical and Chemical) for Water and Wastewater, Filterable Residue (Total Dissolved Solids) (First Revision).

18. Indian standard methods of test for soil, 3025, Part 17, (1984). Methods of sampling and test (physical and chemical) for water and wastewater, Non-filterable residue (total suspended solids).

19. Indian standard methods of test for soil, 3025, Part 21, (2009). Method of Sampling and Test (Physical and Chemical) for Water and Wastewater, Part 21: Hardness (Second Revision).

20. Indian standard methods of test for soil, 3025, Part 44, 1993, RA (2009). Method of Sampling and Test (Physical and Chemical) for Water and Wastewater, Chemical Oxygen Demand (COD) (First Revision).

21. Indian standard methods of test for soil, 3025, Part 56, (2003). Method of Sampling and Test (Physical and Chemical) for Water and Wastewater, Selenium (First Revision)

22. Indian standard methods of test for soil, 3025, Part 58, 2006, RA 2012. Method of Sampling and Test (Physical and Chemical) for Water and Wastewater, Biochemical Oxygen Demand (BOD) (First Revision).

23. Jenny, S. and Malliga, P. (2016). Assessment of different concentrations of organic manure on the growth and yield of Solanum lycopersicum L. (tomato). International Journal of Innovative Research in Science, Engineering and Technology. 5(3): pp 3722-3731.

24. Jenny, S. and Malliga. P. (2018). Biodegradation of lignocellulosic waste using Cyanobacteria and development of organic manure. Int. J. of Life Sci. Res. Vol. 6(4) pp: 199-207.

25. Kalaibharathi, S.; Sowmya, R. and Malliga, P. (2019). Germination study on Vigna radiata (L.). Seeds using Tannery effluent treated with Coir pith and Nava Rasa Karaisal. Chem Sci Rev Lett, 8(30), 210-215.

26. Kayil Veedu, A., S. Muthusamy, U. Pachikaran Unnikannan and S. Palliyath. (2015). Phycoremediation of tannery wastewater using microalgae Scenedesmus sp. International Journal of Phytoremediation. 17: 907-916.

27. Krishna Moorthy. S.; Subramaniyan, V. and Malliga, P. (2012). Effect of Coir Pith Based Cyanobacterial Biofertilizer on Morphological and Yield Characters of Aloe Barbadensis Miller in Pot Experiment. Journal algal biomass utilization. 3(2): pp 33-41.

28. Kulasooriya, S. A. (2011). Cyanobacteria: Pioneers of Planet Earth, Ceylon Journal of Science, 40(2), pp 71-88.

29. Lakshmi, K and Malliga, P. (2014). Treatment of Tannery Effluent using Cyanobacterium (Lyngbya Sp.) with coir pith. International Journal of Scientific Research. Vol. 3(9): 23-27.

30. Lakshmi, K.; Rajakumar, S and Malliga P. (2015). Bioremediation of tannery effluent using Lyngbya sp. with coir pith. Int. J. Sci. Res. Vol. 4 (1):2736-2743.

31. Lovley, D. R. and Coates J. D. (1997). Bioremediation of metal contamination, Curr Opin Biotechnol, 8, pp 285-289.

32. Malliga, P. and Viswajith, V. (2005). Biodegradation of lignin: A search for valuable products. In: Biotechnological applications in environmental management, pp 232-239.

33. Malliga, P. and Viswajith, V. (2007). Coir pith based Cyanobacterial bio fertilizer using Phormidium sp. BDU 5. The patent office Journal issue No.13/2007 pp. 6329-6352.

34. Malliga, P.; Uma, L. and Subramanian, G. (1996). Lignolytic activity of the cyanobacterium Anabena azollae ML2 and the value of coir waste as a carrier for bio fertilizer, Microbios 86, pp 175-183. 
35. Marc Monachese.; Jeremy, P., Burton and Gregor Reida. (2012). Bioremediation and Tolerance of Humans to Heavy Metals through Microbial Processes: a Potential Role for Probiotics? Applied and Environmental Microbiology, Volume 78, pp 6397-6404.

36. Riyaz. M.; Sowmya. R, Jenifer. G, Ketut Gede Dharma Putra, Jenny. S. and Malliga. P. (2019). Biological treatment of tannery effluent using Cyanobacteria and NRK for Sansevieria trifasciata plant growth. Journal of Global Resources, Vol. 6 (1): 141-147. December 2019. DOI:10.46587/JGR.2019.v06i01.022

37. Mohammed Assou.; Madinzi, A., Aboulhassan, M. A. and Salah Souabi. (2014). Removal of Turbidity in Tannery Waste Water: Modelling by the Experimental Design, International Journal of Civil and Environmental Engineering, Vol.36 (2): 1290-1296.

38. Murali Shankar. A.; Henciya, S. and Malliga. P. (2013). Bioremediation of tannery effluent using fresh water cyanobacterium Oscillatoria annae with coir pith International Journal of Environmental Sciences Volume 3 No.6.pp 1881-1890.

39. Mythili, K. and Karthikeyan, B. (2011). Bioremediation of $\mathrm{Cr}(\mathrm{VI})$ from tannery effluent using Bacillus sp. And Staphylococcus sp. International multidisciplinary Research journal. 2 (5): 1460-1463.

40. Nantha, S., K. S. Prakash and J. Abraham. (2010). Cyanobacterial remediation of industrial effluents I. Tannery effluents, New York Science Journal. 3 (12): 32-36.

41. Nivetha, E.; Bela, R, B, Shanmugapriya, N and Malliga, P. (2014). Decolorizing Efficiency of Oscillatoria Subuliformis with Coir Pith in Textile Dye Effluent. Global Journal for Research Analysis. Vol. (10): $72-75$.

42. Noorjahan, C.M. (2014). Physicochemical characteristics, identification of fungi and biodegradation of industrial effluent. J. Environ. Earth Sci., 4: pp 32-39.

43. Pazhanivel, G.; Chandrasekaran, P., Prabha, D.S., Bhuvaneswari, B., Malliga P. and Chellapandi, P. (2011). Effect of Coir Pith Based Cyanobacterial Biofertilizer for Improving Fatty Acid Contents in Arachis hypogaea L. (Groundnut) Oil Seeds. Journal of Advances in Developmental Research .2 (1): 38-41.

44. Rittmann, B. E.; Nerenberg. R., Lee, K. C., Najm. I., Gillogy.T. E., Ehman. G. E. and Adham. S. S. (2004). Hydrogen based hallow- fiber membrane biofilm reactor (MBFR) for removing oxidized contaminants, Water supply 4(1), pp 127-133.

45. Sangita, P. L., U. K. Aruna and R.C. Maggirwar. (2013). Biodegradation of tannery effluent by using tannery effluent isolate. International Multidisciplinary Research Journal. 2(3): 43-44.

46. Selvi, A.; E. Anjugam, R. Devi, B. Madhan, S. Kannappan and B.C. Chandrasekaran. (2012). Isolation and characterization of bacteria from tannery effluent treatment plant and their tolerance to heavy metals and antibiotics. Asian J. Exp. Biol. Sci. 3(1): 34-41.

47. Shanmugapriya, N and Malliga, P. (2013). Textile Effluent treatment using Marine Cyanobacterium (Oscillatoria Subuliformis) with coir pith and removal of Heavy Metals. International Journal of Scientific Research. Vol. 2(12): 484-486.

48. Silambuselvi M., Malini D., Rajakumar S and Malliga P. (2014). Study on bacterial and fungal growth expending the supernatant and pellet released during the degradation of coir pith by Cyanobacterium (Oscillatoria annae). International Journal of Advanced Biotechnology and Research (IJBR). Vol.5 (4): 619-627.

49. Sivaruban, T., S. Barathy, S. Sivakumar, G. Mukesh, D. Ashutosh, K. Ravi kumar and S. Maran. (2014). Microbial removal of high concentration heavy metal in tannery. Research Journal of Pharmaceutical and Chemical Sciences. 5(4): 217-224.

50. Srinivas, G. B. and M. Estari. (2012). Studies of efficacy of immobilized bacteria in tannery effluent treatment. J. Bio. Innov. 2(2): 33-44.

51. Subramaniyan, V. and Malliga, P. (2011). Effect of cyanopith biofertilizer as basal and spray on Zea mays (Corn) cultivation. International Journal of Environmental Sciences. Volume 2, No 2. 649-658.

52. Subramaniyan, V.; Krishna Moorthy, S and Malliga, P. (2012). Analysis of biochemical and yield parameters of Zea Mays (Corn) cultivated in the field supplemented with coir pith based cyanobacterial bio fertilizers. Journal of Algal Biomass Utilization. Vol. 3(3): 54-57.

53. Sugasini, A. and Rajagopal, K. (2015). Characterization of Physicochemical Parameters and heavy metal Analysis of Tannery EffluentInt. J. Curr. Microbiol. App. Sci, 4(9): pp 349-359.

54. Susithra, S.; Hassem banu, S., Lucky, R. and Dawood, N. (2009). Biodegradation of nutrient rich tannery effluent using cell suspension of Pseudomonas putida. Jr. of Industrial Pollution control, 25 (2): 149-154.

55. Thamizhiniyan. P.; Sivakumar P.V., Lenin. M. and Sivaraman. M. (2009). Sugar Mill Effluent Toxicity in Crop Plants, J. Phytol., 1, pp 68-74.

56. U.S. EPA. (1996). "Method 3050 B: Acid Digestion of Sediments, Sludges, and Soils," Revision 2. 